\title{
CORPOS CHEIOS DE SI E DO OUTRO: ENCONTROS ENTRE CRIANÇAS E ADULTOS NA CRECHE
}

\author{
Adriane Soares dos Santos ${ }^{\mathrm{i}}$ \\ Daniela Guimarães ${ }^{\mathrm{ii}}$ \\ Deise Arenhart ${ }^{\mathrm{iii}}$
}

\begin{abstract}
Resumo: Este artigo tem como objetivo compartilhar reflexões que se produziram a partir de uma pesquisa monográfica realizada com crianças de dois anos, no contexto de uma instituição pública de Educação Infantil, na qual focalizamos as relações e sentidos que são mobilizados pelo corpo nos encontros entre crianças e adultos na creche. Os instrumentos de pesquisa utilizados foram: observação e registro em diário de campo, fotografia e entrevista com professoras da turma pesquisada. No diálogo com a empiria, destacamos os movimentos relacionais das crianças entre si, destas com os adultos e destes com as crianças. Os sentidos mobilizados pelo corpo nesses encontros passam por afeto, força, cuidado, cumplicidade, resistência, confiança, poder e controle.
\end{abstract}

Palavras-chave: Corpo, Crianças, Adultos, Creche, Relações.

\section{FULL BODIES OF YOU AND THE OTHER: MEETINGS BETWEEN CHILDREN AND ADULTS AT THE NURSERY}

\begin{abstract}
This article aims to share reflections that were produced from a monographic research conducted with two-year-old children, in the context of a public institution of Early Childhood Education, in which we focus on the relationships and meanings that are mobilized by the body in relational encounters between children and adults in the nursery. The research instruments used were: observation and recording in field diary, photography and interview with teachers of the researched class. In the dialogue with empiricism, we highlight the related movements of children with each other, with adults and with children. The senses mobilized by the body in these encounters go through affection, strength, care, complicity, resistance, confidence, power and control.
\end{abstract}

Keywords: Body, Children, Adults, Nursery, Relationships.

\section{Introdução}

Um corpo não é vazio. Está cheio de outros corpos, pedaços, órgãos, peças, tecidos, rótulas, anéis, tubos, alavancas e foles. Também está cheio de si mesmo: é tudo o que é. (Jean-Luc Nancy) 


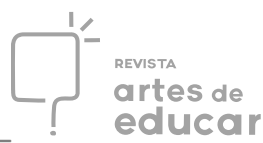

Somos corpos cheios, cheios de água, de células, de pelos, de desejos, de curiosidades. Somos cheios de nós e de outros, que nas interações, nas brincadeiras, nos encontros e no cotidiano vão nos constituindo, nos modificando e nos refazendo.

Nessa direção, este artigo tem como objetivo compartilhar reflexões que se produziram no tempo-espaço de uma pesquisa realizada com crianças de dois anos, na qual focalizamos as relações e sentidos que os corpos, cheios de si e de outros, produzem no encontro com o espaço físico e relacional da creche. Que sentidos e possibilidades têm o corpo para crianças tão pequenas? Que ações e diálogos elas mobilizam por meio da potência do corpo? Como crianças de dois anos lidam com o reconhecimento dos desejos do corpo e os limites, regras e (im)possibilidades da cultura institucional? Que significações o corpo da criança tem para o adulto educador? Em que perspectiva o corpo da criança é alvo da intervenção do adulto? Como se equacionam o cuidado, a proteção, a disciplina?

Essas questões são produzidas, por um lado, pelo reconhecimento do corpo da criança como marca de sua alteridade geracional, sobretudo por sua potência como linguagem, interação, resistência e experiência lúdica (ARENHART, 2016) e, por outro, pelo reconhecimento dos constrangimentos e acomodações que a relação com as instituições sociais da modernidade, especialmente, a escola, produzem na conformação, disciplinamento e docilização dos corpos (FOUCAULT, 2007).

Autores como Vigotski (1991) e Pino (2005) já indicam o corpo, sobretudo a intencionalidade do gesto, como a primeira inscrição cultural da criança, na medida em que o adulto interpreta responsivamente o gesto da criança e nomeia sua intenção com a palavra, inserindo-a no mundo da linguagem. A criança aprende que o gesto se insere num contexto de comunicação, o que depois acontecerá também pela linguagem verbal. Além do gesto, a intencionalidade das crianças no estabelecimento de trocas sociais se exprime pelo olhar, expressões, choros e balbucios (COUTINHO, 2012). As crianças bem pequenas também são curiosas sobre o que pode o corpo fazer e sentir. Ainda bebês, elas pesquisam e exploram o próprio tônus, a flexibilidade, as articulações, os orifícios, sons, a textura da pele e pelos, testemunham a própria existência numa experiência de conhecer a si na relação com o outro. Com o desenvolvimento, essas explorações da criança sobre oquepode o corpo fazer e sentir vão ganhando contornos de brincadeira, sendo o corpo suporte para experiências simbólicas, atuando como brinquedo que se experimenta, se pesquisa, se desafia, canta, dramatiza, narra, dança, fantasia.

Revista Interinstitucional Artes de Educar. Rio de Janeiro, V. 5, N.3- pág. 508-524 set-dez de 2019: "Educação: Corpo em movimento." - DOI: 10.12957/riae.2019.45803 


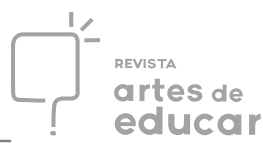

No entanto, quando passamos a olhar para esse sujeito corpo infantil ${ }^{4}$ (SILVA, 2003) no interior das instituições coletivas de educação, é preciso também considerar a ação do contexto na produção desse corpo e as tensões que se produzem entre a ação das crianças e a estrutura institucional da creche.

Nesse caminho, a contribuição de Foucault (2007) é muito importante, no sentido de localizar o corpo como objeto de disciplinamento, esquadrinhamento e controle nas instituições emergentes no mundo moderno, especialmente as escolas. Para o autor, a disciplina é uma anatomia política do detalhe, que se concretiza no controle minucioso do cotidiano, na otimização da eficiência dos movimentos.

A disciplina fabrica assim corpos submissos e exercitados, corpos dóceis [...] aumenta as forças do corpo (em termos econômicos e de utilidade) e diminui essas mesmas forças (em termos políticos de obediência). Em uma palavra: ela dissocia o poder do corpo (FOUCAULT, 2007, p.119).

Ao mesmo tempo, Foucault (2004) afirma a impossibilidade de escaparmos ao poder disciplinar e controlador que circunscreve o corpo, mas também sublinha as possibilidades de resistência:

Nas relações humanas, quaisquer que elas sejam [...] o poder está sempre presente : quer dizer, a relação em que cada um procura dirigir a conduta do outro [...] mas essas relações de poder são móveis, podem se modificar, não são dadas de uma vez por todas (FOUCAULT, 2004, p.276).

Assim, quando pensamos a escola e a organização do tempo, do espaço, a otimização dos gestos, é importante focalizar tanto o esquadrinhamento e o controle, quanto as possibilidades criativas e de contrapoder que se expõem de modo particular na expressão criativa das crianças.

Para Foucault, de acordo com Ravel (2006), ao lado de uma biopolítica como governo de corpos individuais, há uma preocupação moderna com o governo das populações pela normatização (higiene, alimentação, etc) e, paralelamente, uma preocupação com o agir da liberdade humana de dentro do poder, nas práticas de governo de si, nas experiências que afirmam a potência da vida.

Para outros autores, como James, Jenks e Prout (1999), é importante observar tanto os processos de corporificação que as crianças experienciam nos seus mundos sociais, ou seja, a 


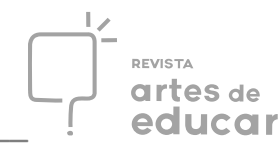

aprendizagem dos usos sociais do corpo, como os caminhos através dos quais elas se colocam como agentes sociais, assimilando, mas também reinterpretando o mundo. Essa dupla perspectiva anunciada pelos referidos autores conduziu nosso olhar sobre as relações corporificadas das crianças entre si e delas com os adultos na pesquisa e nos impulsiona a refletir sobre como a potência de vida sobrepõe-se ao poder sobre a vida no cotidiano da escola.

\section{O campo e os caminhos da pesquisa}

A pesquisa de campo foi realizada com um grupo de crianças de dois ${ }^{5}$ anos numa escola de Educação Infantil da rede federal. Ao longo do processo investigativo, utilizamos como instrumentos de pesquisa a observação e registro em caderno de campo, fotografia e entrevistas com professoras. No decorrer das observações pudemos acompanhar diferentes momentos da rotina do grupo, como o almoço, o lanche, as brincadeiras, a ida à sala de leitura, as andanças e aventuras pelo pátio.

Com base numa perspectiva interpretativa para a pesquisa em Ciências Humanas (SARMENTO, 2008), torna-se possível compreender que o acompanhamento do cotidiano, dos sentimentos e das percepções move os sujeitos/pesquisadores que interagem, interpretam e constroem sentido sobre o que está presente na realidade pesquisada. Assim estaremos também refletindo aqui a mobilização do próprio corpo da pesquisadora no encontro com as crianças e adultos da pesquisa; os desafios, dilemas e possibilidades construídos nesse encontro.

Um dos primeiros dilemas se refere às reservas da pesquisadora acerca de sua aceitação pelos sujeitos da pesquisa, especialmente, pelas crianças. Logo no primeiro momento de ingresso no grupo, pudemos ver as questões da pesquisa pulsando, visto que o corpo das crianças informava à pesquisadora sentimentos que se deslocavam entre a desconfiança e curiosidade; entre receio e o desejo de aproximação.

Quando cheguei à sala do grupo 2, as professoras me apresentaram, informando às crianças que eu estava realizando uma pesquisa e que iria passar alguns dias com o grupo. Na sala já havia uma estagiária, papel esse que já assumi inúmeras vezes, mas agora era diferente, eu estava ali como pesquisadora. Éramos quatro adultos e dez crianças. Assim que a professora Revista Interinstitucional Artes de Educar. Rio de Janeiro, V. 5, N.3- pág. 508-524 set-dez de 2019: "Educação: Corpo em movimento." - DOI: 10.12957/riae.2019.45803 
me apresentou, as crianças me encararam, algumas me ignoraram, outras me olharam desconfiadas, principalmente Giovana ${ }^{6}$ que me encarou e ficou longe; tentei me aproximar, ela sempre se afastava. Amanda e Luíza, no primeiro momento, também não me deram assunto, mas minutos depois me convidaram a brincar puxando o meu braço e me levando em direção aos brinquedos (Diário de Campo, 19/11/2018).

Na cena descrita, evidenciamos a reação das crianças à presença da pesquisadora, manifesta especialmente pelos olhares e pelo movimento de afastamento e/ou aproximação do corpo. Giovana, em uma reação de afastamento, com olhar desconfiado, impôs um limite espacial e corporal na relação com a pesquisadora. Esse limite durou cerca de três dias, até ela começar a buscar aproximação. Em contrapartida, as outras crianças manifestaram fácil aceitação pela presença da pesquisadora e passaram a incluí-la no cotidiano do grupo, convidando-a a participar de suas brincadeiras e interações.

Ao olharmos para esse evento, consideramos importante destacar que, em pesquisa com crianças bem pequenas que ainda não tem a linguagem verbal constituída, o consentimento para o pesquisador participar de seus universos sociais e realizar os procedimentos de pesquisa (observação, fotografia, filmagem, etc.), é dado pela expressividade do corpo. Estar atento a essas manifestações - que podem ser sutis, mas carregadas de intencionalidade - se torna fundamental quando a postura ética na pesquisa passa por considerar as crianças sujeitos ativos e não meros objetos da investigação.

Outra questão que atravessou as relações em campo se referiu a construção de um lugar de pesquisadora junto ao grupo que não se confundisse com o lugar da professora e nem de estagiária da turma. Considerávamos fundamental que a pesquisadora conseguisse realizar trocas e interações próprias ou atípicas do papel do adulto ou professor (CORSARO, 2005), vivendo a relação com proximidade e certo afastamento, para ser capaz de se surpreender com os imponderáveis do grupo. Contudo, a condição de estagiária recentemente vivida pela pesquisadora, por vezes, a colocava num lugar nebuloso; por vezes se indagava se deveria brincar junto ou propor brincadeiras e atividades ao grupo, ou se deveria somente observar e registrar as relações corporais que do brincar emergiam. Fomos percebendo que vivenciar atividades junto às crianças e educadoras aproximaria os vínculos afetivos, ao mesmo tempo que era importante para a pesquisa que a aproximação não impedisse o exercício de conseguir estranhar os movimentos cotidianos que eram estabelecidos. 
Desse modo foi-se construindo um processo de constante vigilância, estranhamento, reflexividade que foi indicando o melhor jeito de estar com os sujeitos da pesquisa. Trazemos uma cena que ilustra as questões aqui abordadas:

As professoras do grupo pediram para as crianças calçarem os chinelos, pois iriam ao pátio. Rapidamente, as crianças pegaram seus respectivos chinelos e se organizaram para descer. Chegando lá, as crianças correram, pegaram os brinquedos, outras brincaram na casinha, enquanto Amanda, João e Gustavo ficaram olhando uma grande poça que tinha-se formado no pátio. Eu observei a cena e tive a ideia de fazer o convite às crianças para brincarem na poça. Pensei, pensei, não sabia de deveria fazer tal ação, pois ali estava com o papel de pesquisadora e não professora ou estagiária. Olhei a poça, olhei as crianças curiosas e fui em direção a elas. Levantei a calça e pisei, as crianças também entraram na poça e começaram a brincar com as folhas. Observei, brinquei com elas. Até que abaixei e coloquei a mão na água, as crianças sorriram e fizeram o mesmo. Foi um momento muito gostoso de brincadeira e descobertas. Pé e mão no chão, na água, nas folhas... enquanto eu pensando se deveria ter interagido e proposto o que eu fiz (Diário de Campo, 20/12/2018).

Essa cena é instigante porque nos convoca a pensar sobre o lugar da pesquisa e do pesquisador com as crianças e, também porque já anuncia a questão central do estudo, ou seja, o lugar do corpo na escola. O movimento reflexivo, o exercício de proximidade/estranhamento coloca-se como chave para a construção do lugar de pesquisadora com crianças na escola. Por outro lado, a interpretação do olhar das crianças e o convite para a exploraçãoda poça, na verdade, tradução do desejo das crianças, admite o corpo no lugar do imponderável, da brincadeira, da expressividade.

A seguir apresentamos as categorias que brotaram da análise dos registros do campo, destacando as relações das crianças entre si, mediadas pelo corpo e as relações dos adultos comas crianças, também pelo caminho corporal.

\section{Movimento relacional criança-criança: força, afeto, cuidado, cumplicidade}

$\mathrm{Na}$ análise sobre os sentidos mobilizados pelo corpo nos encontros das crianças entre si, destacamos essas quatro dimensões: o corpo como força, afeto, cuidado e cumplicidade. 


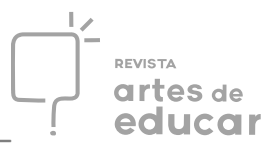

Passaremos a discutir como isso aparece a partir do recorte de algumas cenas/eventos extraídos do diário de campo.

Num primeiro evento, no qual se destaca o corpo como força, estão presentes três crianças: Lorena, João e Paulo. Lorena e João brincam com as cadeiras, enquanto Paulo observa e, logo em seguida, reage através de sua expressão facial, postura corporal e, no fim, o choro.

As crianças do grupo estão brincando na sala, quando decido observar mais atentamente a brincadeira de Lorena e João. As crianças brincam pulando nas cadeiras, dando risadas, se olhando. Paulo está próximo, mas somente observa. Lorena e João não convidam Paulo para entrar na brincadeira. Existem outras cadeiras espalhadas pela sala, mas Paulo não faz o movimento de ir buscá-las para brincar junto, ele somente olha; um olhar que expressa o desejo de brincar com os amigos. Lorena e João não percebem o olhar de Paulo e continuam pulando na cadeira. Paulo pareceperceber-se fora da brincadeira e em um movimento de força tenta tirar Lorena e João de cima da cadeira. Mas as crianças se recusam a sair e continuam brincando. Paulo, então, começa a chorar (Diário de campo, 27/11/2018).

Na cena descrita, podemos observar a força corporal que Paulo tenta impor às outras crianças no momento que tenta interferir na brincadeira com as cadeiras.

Sua presença silenciosa e seu olhar participam da cena, mesmo não sendo notados explicitamente pelos outros. Em dado momento, resolve colocar-se. Naquele instante, o corpo é comunicação, expressa sentidos, desejo. Tentar tirá-los da cadeira e chorar são modos de fazer-se presentepela linguagem corporal. Afetos, encontros dos corpos que potencializam a comunicação estão presentes. Perguntamo-nos: qual poderia ser o papel do adulto nesta situação?

De acordo com Falk (2004), o não-intervencionismo adulto na atividade independente das crianças não é o mesmo que abandono e é uma importante condição para o desenvolvimento da linguagem e da autonomia. Nessa cena, é importante o tempo de observação do menino e o não atropelo de seus sentidos. No entanto, o contorno verbal, o enriquecimento da cena com a palavra, talvez pudesse contribuir para que os sentidos de Paulo ganhassem um novo lugar.

$\mathrm{Na}$ cena registrada a seguir verificamos um movimento de cuidado entre as crianças.

A professora do grupo tinha solicitado que as crianças calçassem os sapatos para que todos pudessem descer para brincar no pátio. Cada criança pegou 
seu sapato para calçar; porém, Lorena percebeu que João estava sem o seu. Foi até o local onde os calçados ficam, pegou o do amigo, e o chamou para calçar. João levou na brincadeira, mas em seguida, defronte ao toque e a insistência de Lorena, puxando seus pés e pernas, ele permitiu que a amiga colocasse seu sapato (Diário de Campo, 12/12/2018).

No que tange à dimensão do cuidado na relação e interação entre as crianças, observamos os toques, os gestos e os olhares. Nas ações entre os pares, as relações criançacriança eram permeadas por afetos de alegria e consideração do outro. De maneira sutil, muitas vezes sem a mediação da palavra, as crianças mostravam atenção para com as outras.

Para Guimarães (2011), o cuidado dilata as possibilidades da educação. Trata-se de atenção ao outro, responsividade. É possível notar entre as crianças, mergulhadas em ricas interações dialógicas com os adultos, iniciativas de cuidado com as outras crianças. O corpo materializa esse movimento.

A partir de uma perspectiva histórico-cultural e social, a criança constitui-se subjetivamente nas relações que constrói com o outro desde o seu nascimento; então, o cuidado, como modo de relação e reconhecimento do outro, pauta e marca os sentidos de si mesmas por parte das crianças. (ARENHART; GUIMARÃES; SANTOS, 2018, p.1683).

O contexto de "calçar os sapatos" e a abertura dos adultos para as iniciativas das crianças, permitem que Lorena coloque-se a ajudar João, evidenciando o reconhecimento do corpo e da presença do outro, a partir das experiências já vivenciadas no cotidiano. Aconvivência e a experiência decorrente do fato de saberem ser necessário calçar os sapatos para irem ao pátio mobilizamLorena, que já estava com os seus sapatos calçados, em relação à João.

Destacamos a seguir outra cena do brincar das crianças que realça o movimento relacional criança-criança a partir de interações através de seus corpos e de seus olhares. A ação registrada refere-se à organização das crianças entre si na brincadeira com as mochilas, em que se destaca a cumplicidade e confiança entre as crianças na proteção do espaço criado para brincar.

As crianças constroem uma espécie de muro com as mochilas e brincam dentro do espaço que se torna delimitado. A brincadeira se inicia com Bruno e Lorena. As outras crianças primeiro olham, observam o movimento que 
estava sendo construído, logo em seguida começam a se aproximar e adentram o brincar (Diário de campo, 10/12/2018).

A riqueza da cena no que tange às interações corporais entre as crianças e seus pares refere-se aos olhares. Coutinho (2012) pontua que as crianças bem pequenas intervêm na ação dos pares, ainda que muitas vezes o façam recorrendo a formas de comunicação quase invisíveis aos olhos adultos que, apressados em seus cotidianos, muitas vezes não se permitem capturar as fluídas formas de expressão das crianças. Tal intervenção ocorre à medida que, no decorrer de toda brincadeira, poucas palavras são proferidas, a comunicação entre as crianças ocorre através dos olhares e do corpo. Coutinho contribui com essa observação:

A questão do olhar mostra-se na relação entre as crianças como um elemento relevante de percepção do outro e de comunicação com esse outro, o olhar é um canal de estabelecimento de um complexo diálogo, muitas vezes gerido pelo corpo, entre as crianças (COUTINHO, 2012, p. 249).

Nesse sentido, a dimensão da cumplicidade e confiança no movimento relacional criança - criança se expressa, à medida que o olhar permite a captação dos acontecimentos e ao mesmo tempo permite a comunicação dos sentimentos, dos combinados, das ações recíprocas (COUTINHO, 2012).

\section{Movimento relacional criança - adulto: afeto, confiança, resistência}

Ao observarmos as relações corporais que as crianças construíam com os adultos educadores, destacamos a dimensão do afeto, da confiança e da resistência. As relações de afeto e confiança através do corpo se evidenciavam em diversos momentos do cotidiano do grupo, como no brincar, na alimentação e no banho.

As crianças estavam brincando com diversos brinquedos. Tinha bola, boneco, peças de madeira e animais. Paulo e Luíza estavam brincando juntos com os animais, quando começaram a disputar um dos brinquedos. Paulo puxava para um lado, enquanto Luíza puxava para o outro. Em determinado momento a menina solta o brinquedo e Paulo cai deitado no tatame. Ele então começa a chorar e olha ao seu redor buscando as professoras. As 
professoras estavam um pouco afastadas do grupo, dando atenção para outras crianças que não estavam brincando no tatame. $\mathrm{O}$ adulto mais próximo era eu. Paulo me olha, e vem em minha direção. Eu estava sentada, ele senta em meu colo e eu então o abraço. Ficamos assim durante alguns minutos até que ele se acalma, me olha e volta a brincar com as crianças, só que agora Paulo ficou mais próximo de mim, chegando a abraçar minha perna enquanto brincava (Diário de Campo, 12/12/2018).

Na cena descrita, a dimensão da confiança mostra como os corpos das crianças buscam os corpos dos adultos de referência em situações em que as mesmas se sentem desprotegidas ou frustradas. O toque, o carinho, o aconchego e a segurança que o corpo do adulto promove para a criança são descritos no relato do diário de campo no momento em que Paulo se acalma e depois volta a brincar, só que agora mais próximo ao adulto.

Para Wallon (2005), o corpo é lugar de expressão da emoção. Nos primeiros meses de vida as manifestações corporais são reflexas, impulsivas. Ao serem respondidas pelos adultos, ao afetarem o ambiente em torno, tornam-se expressivas, modo de comunicação, contato com o outro. Olhar, toque, diálogo pela via corporal marcam a vida relacional da criança pequena.

No início, a afetividade é pura emoção, irradiando-se por contágios ou imitação. O choro, o riso, expressões faciais são propagadas nos contatos afetivos. As trocas dependem da presença concreta do parceiro. Aos poucos, as manifestações afetivas incorporam as construções da linguagem verbal. Instalam-se formas verbais de vinculação afetiva.

As influências afetivas que rodeiam as crianças desde o berço não podem deixar de exercer uma ação determinante na sua evolução [...] assim se mistura o social com o orgânico [...] a sensibilidadeda criança se estende ao ambiente; ela reproduz os seus traços [...] esse desdobramento que também é uma alienação de si em outrem, implica uma segunda fase inversa (WALLON, 2005, p.141).

Posteriormente, a capacidade de atravessar o contato sensível também pela razão e pela linguagem verbal vão especializando e refinando a expressão afetiva.

Quando Paulo busca o adulto com o olhar ou busca o abraço do adulto, ficando entre o contato do educador e a brincadeira entre os parceiros, mostra transitar entre o afeto garantido no toque, no diálogo tônico, e o afeto que se constrói nas interações onde corpo, palavra, objetos estão em jogo na construção de sentido sobre si e sobre as relações. 
A seguir, trazemos também um trecho de uma entrevista realizada com uma das professoras do grupo de crianças que evidencia a percepção das educadoras no que tange à necessidade da confiança que as crianças expressam por meio de seus corpos:

\begin{abstract}
"A relação corporal é muito importante na relação entre professor $e$ criança, ao longo do ano a gente vai percebendo a diferença dessa relação corporal, porque no início do ano o corpo deles em relação com o nosso tem uma restrição muito grande. Por exemplo, algumas crianças ainda não querem ter o contato, a gente também não se sente também tão prontos para estar entrando em certos tipos de contato, como na troca de fraldas, teve criança aqui na inserção que não deixava a gente trocar a fralda porque é algo muito intimo para essa criança. Então, é uma relação corporal que faz parte de uma afetividade, que necessita de uma criação de vínculos entre nós, professores, com as crianças e entre as crianças para que essa relação aconteça. E aí, conforme vai passando o tempo, a gente vai percebendo como eles buscam o nosso corpo, o nosso colo, como a gente se torna referência para eles né. Em outros espaços eles querem a nossa presença e a presença do nosso corpo para se sentirem seguros [...]".
\end{abstract}

Nas relações corporais das crianças com os adultos, destacamos também a dimensão da resistência ao instituído pelo adulto. O corpo que se coloca, que contraria, que desobedece a alguns pedidos das professoras. Um corpo que é movimento e busca movimentar-se a todo o momento. No decorrer da pesquisa, observamos diversos momentos em que o corpo resiste e não se acomoda ao instituído. Destacamos, a seguir, um relato do diário de campo que evidencia tal dimensão.

Após o momento de banho no chuveirão, as professoras convidam as crianças a retornarem para a sala. As professoras enrolam as crianças com suas toalhas e todos voltam para a sala de referência do grupo. Começa, então, a troca de roupa, as professoras vão chamando criança por criança para trocar a roupa, pedindo que enquanto isso as demais brincassem no tatame, pois o chão estava molhado e poderia causar acidentes. Giovana estava brincando com seu corpo, mexia em seu pé, na toalha, até que começou a sair do tatame. Quando umas das professoras viu, chamou a atenção da menina. Giovana voltou para o tatame, distraiu-se, porém, minutos depois saiu novamente do espaço. Uma das professoras então pegou Giovana no colo e a colocou novamente no tatame dizendo que ela não poderia sair dali. Giovana então começou a observar as outras crianças e as professoras. Enquanto observava as professoras, colocou um pé para fora do tatame, depois outro, depois a perna e quando me dei conta novamente ela estava fora do tatame. A menina começou a correr pela sala e acabou escorregando e levando um tombo no molhado. (Diário de Campo, 21/12/2018). 


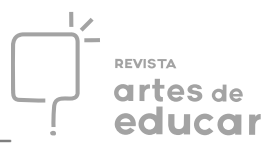

Na cena descrita, a dimensão da resistência à obediênciaevidencia-se na ação corporal da criança defronte a ação do adulto educador. Giovana, diante de uma ordem para manter-se no tatame, através de seu corpo se expressa de modo a refutar o pedido da professora.

Para Foucault (2007) a técnica do comando e a moral da obediência conformam o corpo nas instituições disciplinares. Na mesma direção, Kohan (2003, p.81) afirma:

Nas escolas os indivíduos têm experiências de si que modificam sua relação consigo mesmo numa relação precisa. São experiências demarcadas por regras e procedimentos que incitam subjetividades dóceis, disciplinadas e obedientes.

Na cena descrita, há uma sequência de gestos prescritos, um acordo tácito de movimentos que é desafiado pelo corpo explorador e inquieto de Giovana. Para Kohan (2003), para além da infância determinada pela instituição escolar moderna, a infância é também possibilidade do novo, experiência alteritária, símbolo da afirmação, tempo de resistência e criação de novos modos de existência. Trata-se de compreender que "quando a infância é amiga da experiência, longe de ser uma fase a ser superada, ela se torna uma situação a ser estabelecida, atendida alimentada" (KOHAN, 2003, p.245).

Os pés de Giovana que insistem em sair do tatame, levam-nos a perguntar: quais os sentidos da criança nessa situação? Qual o convite dela? Qual a sua experiência? Para além da contenção do corpo, da insistência na conformação, como essa situação pode ser interpretada pelo adulto, covocando-a a outras ações?

\section{Movimento relacional adulto-criança: afeto, cuidado, poder, controle}

O último movimento relacional destacado é o movimento adulto-criança. Conforme já colocado, no decorrer das observações ressaltamos que esse movimento é permeado pela dimensão do cuidado como atenção, ao mesmo tempo do cuidado como proteção, poder e controle. Ressaltamos também a percepção da posição de um adulto que brinca e explora junto com as crianças e que, através do seu corpo, evidencia seus limites e potencialidade nas práticas e experiências cotidianas. 


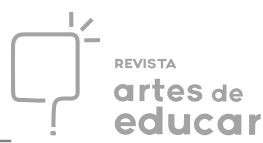

Consideramos importante pontuar que, para além do cuidado numa perspectiva sanitarista e higienista, a pesquisa evidenciou o cuidado como ética e modo de relação responsivo com as crianças.

Mais do que como momento da rotina institucional, ação sobre a ação das crianças, cuidar é um modo de relação do adulto com a criança nos atos pedagógicos/educacionais. Ao considerarmos a ação adulta, cuidar é estar atento a si e ao outro, é desenvolver um modo responsivo e responsável de contato, é escutar (com todos os sentidos), responder, compreender ativamente a criança (ARENHART; GUIMARÃES; SANTOS, 2018, p.1683).

Desse modo, na contramão da perspectiva do cuidado meramente protetivo e assistencial é importante construirmos um olhar para as crianças pequenas como sujeitos ativos, relacionais. É importante compreendermos a qualidade das ações dos educadores nas relações institucionalizadas com as crianças, considerando suas possibilidades de afetá-las, desenvolvendo diálogo, atenção e contato.

No momento registradoa seguir, a professora convidaHugo, que estava brincando, para trocar a fralda, aparentemente "cheia". De mãos dadas, a professora e o menino se dirigem ao local da troca de fralda. Amanda, logo que percebe tal movimento, pega uma cadeira e se coloca ao lado da professora, observando suas ações.

A professora convida Hugo para trocar a fralda. O menino tinha um brinquedo em suas mãos e de mãos dadas com a professora vai em direção ao local destinado para a troca da fralda. Hugo continua brincando, enquanto a professora conversa com ele, pergunta se ele fez cocô, tira sua roupa de maneira lenta e carinhosa. É notório o cuidado e o olhar atento que a professora tem durante todo o processo. Amanda observa o movimento da professora comHugo, então pega uma cadeira e se coloca ao lado da educadora. A menina então pergunta "Tem cocô?". A professora ri e explica que não. Amanda continua ali conversando com a professora e comHugo, observando, acariciando a cabeça do amigo (Diário de campo, 20/12/2018).

A ação registrada é potente e importante para refletirmos acerca da dimensão do cuidado nas interações corporais entre o adulto e a criança, na medida em que tal ação não ocorreu de forma mecânica e sistemática, mas sim de modo zeloso e atencioso. A escuta e olhar atento da professora, tanto para o Hugo quanto para Amanda, revelam um modo responsivo e responsável de contato permeado por cuidado e afeto, fazendo-nosrefletir sobre 


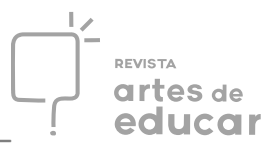

as sutilezas de momentos de cuidado como o banho, a troca de roupa e a alimentação que promovem contatos e interações singulares entre professoras e crianças, fortalecendo relações e o estreitamento de vínculos.

No que tange à dimensão do poder e do controle nas relações construídas entre adultos e crianças, era comum um corpo da professora não disponível para a brincadeira, muitas vezes em pé e distante. Ao mesmo tempo, a contenção do brincar com falas como: "Não pode correr. Não pode subir. Não mexe nisso...”. O não marcava um lugar de impossibilidade.

Contudo, como vimos na cena em que Giovana resiste à ordem de permanecer no tatame, o poder e o controle adulto não é vivido sem resistência por parte das crianças. Ainda que bem pequenas, é importante destacar a capacidade das crianças de expressarem seus desejos (COUTINHO, 2012), anunciando, dentro da ordem instituída, uma nova ordem social emergente (FERREIRA, 2002). Assim, pensamos que essa dualidade já anunciada no início desse texto - entre a disciplina formatadora da escola e a alteridade das crianças - nos indaga na reflexão sobre a docência: como pensar o papel do professor diante da conformidade a que se vincula a função histórica da escola e a expressividade que emerge do corpo como potência para as crianças? Como deslocar a significação de negatividade atrelada ao corpo (não corre, não sobe, não mexe) para enxergar como possibilidade os anúncios que emergem das crianças?

Nessa trilha, indagamos sobre a conexão das professoras com a experiência da infância ou com a infância como experiência.

A cultura adultocêntrica leva-nos a uma espécie de esquecimento do tempo da infância. Com este esquecimento passamos, então, a cobrar das crianças uma postura de seriedade, imobilidade e linearidade, matando pouco a pouco aquilo que elas possuem de mais autêntico - sua espontaneidade, criatividade, ousadia e sensibilidade expressas em seus gestos e movimentos (SAYÃO, 2002, p.3).

Sayão (2002) também considera ser necessário que, nos processos de formação dos profissionais que atuam com as crianças pequenas, seja incluído o olhar para nós mesmos; é preciso aprender a conhecer as reações de nossos corpos ao toque, à música, aos odores. Tal movimento de autoconhecimento do corpo é possível também ser construído juntamente com as crianças, ao se permitir tocar e ser tocado nas brincadeiras, a dançar junto e sentir os diferentes ritmos com as crianças, a experienciar em conjunto as sensações corporais 
permitidas pelo meio e pelas propostas realizadas. No que tange a tal dimensão evidenciamos a fala de umas das professoras do grupo durante entrevista realizada:

\begin{abstract}
"Com o tempo colocamos tantas outras coisas como prioridade e acabamos esquecendo do nosso corpo[...] muitos adultos esquecem como brincar, e o legal de estar com as crianças é que elas te ensinam a como brincar, a como viver, a como ter a relação com o corpo e com o espaço. Porque na verdade elas aprendem a brincar brincando, só que elas estão dispostas a fazer isso. Elas não estão nem aí para o que o mundo vai pensar, elas querem viver, elas querem vivenciar intensamente, que é uma coisa que às vezes eu acho que nós professoras precisamos fazer, sair dessa padronização e tentar aprender com as crianças como viver intensamente, descobrir o mundo intensamente[...] A possibilidade de aprender com as crianças a conhecer esse mundo, a conhecer esse outro, a nos reconhecer, porque eu acho que a gente acaba com o tempo, a gente não reconhece mais o nosso próprio corpo [...] Olhar as possibilidades do nosso corpo e as possibilidade do nosso corpo no espaço e na relação com as crianças".
\end{abstract}

Enfim, a partir da observação de cenas de interação entre as crianças e delas com os adultos foi possível perceber importantes desafios da docência na creche. Destacamos, de modo especial, o de lidar com o lugar de poder do adulto; ou seja, com as ações sobre ações das crianças, inerentes à instituição educacional, sem invisibilizar seus gestos expressivos e criativos.

Nessa perspectiva, é importante atentar para a construção de um corpo adulto disponível para o que emerge dos movimentos relacionais com as crianças; um corpo atento ao sentido das ordens instituídas; um corpo que se enche de si e do outro para indagar a própria forma de existir... Eis aí alguns anúncios que a própria pesquisa permitiu e que nos inspiram na construção de uma pedagogia das relações, dos afetos, numa pedagogia de corpo inteiro.

\title{
REFERÊECIAS
}

ARENHART, Deise. Culturas infantis e desigualdades sociais. Petrópolis, RJ: Vozes, 2016.

ARENHART, Deise; GUIMARÃES, Daniela; SANTOS, Núbia Oliveira. Docência na Creche: o cuidado na educação das crianças de zero a seis anos. Educação \& Realidade. Porto Alegre, v. 43, n. 4, p. 1677-1691, out./dez. 2018.

CORSARO, William. Entrada no campo, aceitação e natureza da participação nos estudos etnográficos com crianças pequenas. In: Educação e Sociedade: Revista de Ciência da Educação. Vol. 26, maio/ago-2005. Campinas, SP: Cedes.

Revista Interinstitucional Artes de Educar. Rio de Janeiro, V. 5, N.3-pág. 508-524 set-dez de 2019: "Educação: Corpo em movimento." - DOI: 10.12957/riae.2019.45803 
COUTINHO, Ângela Scalabrin. O corpo dos bebês como lugar do verbo. In: ARROYO, M.; SILVA, M. R. (orgs.): Corpo Infância: exercícios tensos de ser criança.Petrópolis, RJ: Vozes, 2012.

FALK, Judit. Educar os três primeiros anos: a experiência de Lòczy. Araraquara, SP: JM Editora, 2004.

FERREIRA, Maria Manuela M. "A gente aqui o que gosta mais é de brincar com os outros meninos"- as crianças como atores sociais e a (re) organização social do grupo de pares no quotidiano de um Jardim de Infância. Porto: Universidade do Porto (tese de doutorado), 2002.

FOUCAULT, Michel. Vigiar e punir: histórias das violências nas prisões. $33^{\mathrm{a}} \mathrm{ed}$. Rio de Janeiro: Vozes, 2007.

A ética do cuidado de si como prática da liberdade (1984) IN:

FOUCAULT, Michel. Ditos e Escritos, vol V. Rio de Janeiro: Forense Universitária, 2004.

GUIMARÃES Daniela. As relações entre os bebês e os adultos na creche: o cuidado como ética. São Paulo: Cortez, 2011.

JAMES, A.; JENKS, C.; PROUT, A. O corpo e a infância IN: KOHAN, Walter \& KENNEDY, David (orgs). Filosofia e Infância: possibilidades de um encontro. Rio de Janeiro: Vozes, 1999.

KOHAN Walter. Infância: entre Educação e Filosofia. Belo Horizonte: Autêntica, 2003.

PINO, Angel. As marcas do humano -: as origens da constituição cultural da criança na perspectiva de Lev S. Vigotsky. São Paulo: Cortez, 2005.

RAVEL, Judith. Nas origens do biopolítico de Vigiar e Punir ao pensamento da atualidade IN: GONDRA, José \& KOHAN, Walter (orgs.). Foucault 80 anos. Belo Horizonte: Autêntica, 2006.

SAYÃO, Deborah Thomé. Corpo e movimento: alguns desafios para a Educação Infantil.Revista zero a seis, -. UFSC, Santa Catarina, v. 4, n. 5, p.1-11, jan/jul. 2002.

SARMENTO, Manuel Jacinto. Sociologia da Infância: correntes e confluências. In: SARMENTO, M. J. e GOUVEA, M. C. S. De (orgs). Estudos da Infância: educação e práticas sociais.Petrópolis/RJ: Vozes, 2008.

SILVA, Maurício Roberto. Trama Doce-Amarga: exploração do trabalho infantil e cultura lúdica.São Paulo: HUCITEC; IJUÍ: Unijuí, 2003.

VIGOTSKI, Lev Semionovich. A formação social da mente. $4^{\text {a }}$ ed. São Paulo: Martins Fontes, 1991. 
WALLON, Henri. A evolução psicológica da criança. Lisboa/Portugal: Edições 70, 2005.

\footnotetext{
i Graduada em Pedagogia pela UFRJ. Professora substituta do CREIR - Centro de Referência em Educação Infantil do Colégio Pedro II, em Realengo, Rio de Janeiro. Email: adrianesoares95@gmail.com. ORCID

ii Professora associada da Faculdade de Educação da UFRJ. Doutora em Educação pela Pontifícia Universidade Católica do Rio de Janeiro/PUC. Email: danguimaraes@uol.com.br. ORCID

iii Professora adjunta da Faculdade de Educação da UFRJ. Doutora em Educação pela Universidade Federal do Rio de Janeiro/UFF. Email: deise.arenhart@ hotmail.com. ORCID

${ }^{4}$ Para Silva, o corpo não se separa da noção de sujeito. Todas as inscrições sociais e afetivas que o constituem (a família, a escola, os grupos de pares, a mídia, a religiosidade, a sexualidade etc) são aprendidas e interpretadas porque incorporadas. O corpo, assim, "[...] é essa superfície da natureza humana que se traduz na materialidade do ser social perante o mundo" (SILVA, 2003, p. 273).

${ }^{5}$ A escolha por olhar os encontros relacionais mobilizados pelo corpo entre crianças de dois anos e destas com os adultos, tem a ver por ser uma faixa etária na qual as crianças possuem o corpo como linguagem semiótica privilegiada na interação com o outro, estando num processo de conquista da linguagem verbal.

${ }^{6}$ Utilizamos nomes fictícios para nos referimos às crianças nos eventos descritos, pois, ao avaliarmos as cenas e a condição limitada de consentimento do uso dos nomes verdadeiros que uma criança de dois anos apesenta, consideramos que o critério de proteção de suas identidades, nesse caso, se aproximaria mais de nossa concepção ética de pesquisa.
} 